\title{
Occurrence and genetic characterization of Toxoplasma gondii and Neospora caninum in slaughtered domestic rabbits in central China
}

\author{
Weifeng Qian*, Wenchao Yan, Chaochao Lv, Rongzhen Bai, and Tianqi Wang \\ College of Animal Science and Technology, Henan University of Science and Technology, No. 263 Kaiyuan Road, Luolong District, \\ Luoyang 471003, PR China
}

Received 9 April 2019, Accepted 24 May 2019, Published online 14 June 2019

\begin{abstract}
Currently, information on the occurrence and genetic characterization of Toxoplasma gondii and Neospora caninum in tissues of rabbits in China is lacking. In this study, brain and heart samples from 470 slaughtered domestic rabbits were collected in Henan Province, Central China. The occurrence rate of $T$. gondii and $N$. caninum DNA detected by nested PCR was $2.8 \%$ and $2.1 \%$, respectively. There were no significant differences $(p>0.05)$ in the frequency of the two parasite infections in relation to sex, breed, and region. Three out of 13 T. gondii-positive samples were completely or partially genotyped at 11 genetic markers using PCR-RFLP, and one was identified as ToxoDB genotype \#9. For $N$. caninum, three different sequences at the ITS1 region and two genotypes at the MS5 microsatellite locus were identified. To our knowledge, this is the first genetic characterization of $N$. caninum isolates from rabbits.
\end{abstract}

Key words: Toxoplasma gondii, Neospora caninum, Rabbit, Genetic characterization.

\begin{abstract}
Résumé - Présence et caractérisation génétique de Toxoplasma gondii et Neospora caninum chez des lapins domestiques abattus en Chine centrale. Nous manquons actuellement d'informations sur la présence et la caractérisation génétique de Toxoplasma gondii et Neospora caninum dans les tissus de lapins en Chine. Dans cette étude, des échantillons de cerveau et de cœur de 470 lapins domestiques abattus ont été recueillis dans la province du Henan, dans le centre de la Chine. Le taux de présence d'ADN de $T$. gondii et $N$. caninum, détecté par PCR imbriquée, était de $2,8 \%$ et $2,1 \%$, respectivement. Il n'y avait pas de différence significative $(p>0,05)$ dans la fréquence des deux infections parasitaires en fonction du sexe, de la race et de la région du lapin. Trois des 13 échantillons positifs pour $T$. gondii ont été complètement ou partiellement génotypés au moyen de PCR-RFLP sur 11 marqueurs génétiques, et un a été identifié comme étant le génotype \#9 de ToxoDB. Pour $N$. caninum, trois séquences différentes de la région ITS1 et deux génotypes du locus microsatellite MS5 ont été identifiés. À notre connaissance, il s'agit de la première caractérisation génétique d'isolats de $N$. caninum provenant de lapins.
\end{abstract}

\section{Introduction}

Toxoplasma gondii infections are widely prevalent in warm-blooded vertebrates, including humans and rabbits worldwide, and can cause life-threatening toxoplasmosis in immunocompromized individuals. Fatal cases of toxoplasmosis in domestic rabbits have been reported in a few countries $[6,8]$. It is estimated that up to one-third of the world's human population has been infected with T. gondii [8]. The consumption of undercooked or raw meat containing tissue cysts is the primary risk factor for human $T$. gondii infections $[8,25]$. Rabbit meat is one of the most nutritional white meats, and is very popular in China. Rabbits can be infected by ingestion of food or water contaminated with $T$. gondii oocysts from feline excrement, or by transplacental transmission of $T$. gondii to offspring [8].

*Corresponding author: qwf2012@yeah. net
Humans may become infected by eating undercooked rabbit meat, or from hand-to-mouth processes after slaughtering, skinning rabbits or dealing with undercooked or raw rabbit meat [1]. So far, only a few surveys have focused on $T$. gondii infection in domestic and wild rabbits in China [4, 13, 15, 24, 27]. However, information on the prevalence of $T$. gondii DNA in the tissues of domestic rabbits in China was not available.

Neospora caninum is similar to $T$. gondii in morphology and life cycle, and is one of the most important causes of abortion in cattle worldwide [7]. Canids are the definitive hosts, whereas many other animal species, including rabbits, are intermediate hosts [9]. There are no natural or experimental data on neosporosis in rabbits. To date, there has been only one report on the seroprevalence and DNA detection of $N$. caninum in wild rabbits (Lepus tolai) in China; however, the survey failed to detect $N$. caninum DNA from the tissues [4]. In spite of the worldwide distribution and broad host range of $N$. caninum, 
no data on the genetic characterization of rabbit-derived $N$. caninum isolates are available internationally.

The aim of this study was to determine the occurrence and genetic characterization of $T$. gondii and $N$. caninum from slaughtered domestic rabbits in Henan Province, Central China.

\section{Materials and methods \\ Ethics statement}

The research protocol was reviewed and approved by the Research Ethics Committee of Henan University of Science and Technology.

\section{Specimens}

Between January 2017 and October 2018, brain and heart samples of 470 slaughtered domestic rabbits were collected from seven food markets in Luoyang, Zhengzhou, and Nanyang cities, Henan Province, central China. Each sample was placed into an individual clean self-sealing bag, and the information on the sex, breed, and market of animals was also recorded. All the tissues collected were frozen at $-20{ }^{\circ} \mathrm{C}$.

\section{Detection of $T$. gondii and $N$. caninum DNA}

Approximately 1-2 g tissue was taken selectively from different anatomic regions of each tissue, and the specimen was subsequently homogenized in $3 \mathrm{~mL}$ of sterile phosphatebuffered saline (PBS). Genomic DNA was extracted from $300 \mu \mathrm{L}$ of each homogenized tissue suspension using the commercial TIANamp Genomic DNA kit (TianGen, Beijing, China). Extracted DNA was stored at $-20{ }^{\circ} \mathrm{C}$ until analysis. Molecular detections were carried out by nested PCR amplification based on the $T$. gondii $\mathrm{B} 1$ gene and $N$. caninum NC5 gene, respectively, as described previously $[17,18]$. DNA of the T. gondii RH strain and N. caninum Nc-LY-Cow1 strain [19] was used in each analysis as the positive control, respectively. Distilled water was used in each analysis as the negative control.

\section{Genotype identification}

Toxoplasma gondii genotyping was carried out using the PCR-RFLP method based on genetic markers SAG1, $\left(3^{\prime}+5^{\prime}\right)$ SAG2, alt. SAG2, SAG3, BTUB, GRA6, c22-8, c29-2, L358, PK1, and Apico, as described previously [22]. The ITS1 region of the $N$. caninum NC5 gene positive DNA samples was amplified by nested PCR using the primers NN1 and NN2 as external primers, and NP1 and NP2 as internal primers, as described previously [10]. Multilocus microsatellite genotyping of N. caninum was done based on genetic markers MS4, MS5, MS6A, MS7, MS8, MS10, and MS12, as described previously [20]. DNA of N. caninum Nc-LY-Cow1 and distilled water were used in each analysis as the positive and negative controls, respectively. Two-directional sequencing of positive PCR products was done by Sangon Biotech Co., Ltd., (Shanghai, China). Nucleotide sequences obtained were aligned with each other and with available sequences in GenBank, using ClustalX 2.0, and the default setting, with manual adjustment. A neighbor-joining tree based on the ITS1 sequences was generated using MEGA7 software. The evolutionary distances were computed using the maximum composite likelihood method, and the reliability of branches in the tree was assessed by bootstrap analysis using 1000 replicates.

\section{Statistical analysis}

Chi-square analysis was performed to assess the correlation between the occurrence of T. gondii and $N$. caninum DNA and the sex, breed, and region of rabbits using SPSS, version 11.5 (Statistical Package for the Social Sciences).

\section{Results and discussion}

The occurrence rates of $T$. gondii and $N$. caninum DNA in slaughtered domestic rabbits in this study are presented in Table 1 . DNA of $T$. gondii and $N$. caninum was detected in $13(2.8 \%)$ and $10(2.1 \%)$ of 470 rabbits, respectively. Coinfection with $T$. gondii and $N$. caninum was found in one rabbit $(0.2 \%)$. The occurrence rate of $T$. gondii DNA in domestic rabbits in this study was lower than that $(6.4 \%)$ in wild rabbits from Shandong Province, eastern China [4]. To our knowledge, this study is the first molecular evidence of $N$. caninum DNA in rabbits in China. The survey conducted by Cong et al. [4] failed to detect $N$. caninum DNA from wild rabbits and showed a seroprevalence rate of $0.8 \%$ in Shangdong Province, China. The occurrence rate $(2.1 \%)$ of $N$. caninum DNA in domestic rabbits in this study was similar to that $(2.8 \%)$ in cottontail rabbits (Sylvilagus floridanus) in Italy [26], but lower than that $(10.5 \%)$ in wild rabbits (Oryctolagus cuniculus) in the UK [12].

Similar occurrence rates of $T$. gondii and $N$. caninum DNA were found in the different region, breed, or sex groups, with no significant differences $(p>0.05)$. In different regions, the occurrence rates were $2.1 \sim 3.2 \%$ for $T$. gondii and $1.6 \sim 2.4 \%$ for $N$. caninum, respectively. The occurrence rates in Chinese rabbits and New Zealand rabbits were $2.8 \%$ and $2.7 \%$ for $T$. gondii, $2.5 \%$ and $1.4 \%$ for $N$. caninum, and in male and female rabbits $2.4 \%$ and $3.2 \%$ for $T$. gondii, and $1.6 \%$ and $2.7 \%$ for $N$. caninum, respectively (Table 1 ).

In the present study, $T$. gondii DNA was detected mostly in brain tissue (10/13), consistent with a previous report by de Lima et al. [5]. N. caninum DNA was detected mostly in hearts $(8 / 10)$, like the findings reported by Gondim et al. [11] in sparrows, and indicating that the heart should be included in molecular epidemiology studies of $N$. caninum.

In this study, only 1 out of $13 \mathrm{~T}$. gondii-positive samples gave complete genotyping results at all 11 gene loci, and was identified to ToxoDB genotype \#9, and two samples were genotyped at four and two genetic loci, respectively (Table 2). In China, ToxoDB genotype \#9 is a predominant genotype, and has been found previously in a number of hosts in different regions including Henan Province [16, 23]. However, data on the genetic characterization of rabbit-derived $T$. gondii isolates in China are limited. So far, only two studies have reported one genotype III isolate from domestic rabbits [27] and two ToxoDB genotype \#9 isolates from wild rabbits [4] in China. These 
Table 1. Occurrence of Toxoplasma gondii and Neospora caninum DNA and risk factors for infection in domestic rabbits in Henan Province, central China, based on PCR.

\begin{tabular}{|c|c|c|c|c|c|}
\hline Variable & $\begin{array}{l}\text { No. of } \\
\text { rabbits }\end{array}$ & $\begin{array}{c}T . \text { gondii DNA } \\
\text { positive rabbits (\%) }\end{array}$ & $p$-value & $\begin{array}{l}N . \text { caninum DNA } \\
\text { positive rabbits (\%) }\end{array}$ & $p$-value \\
\hline \multicolumn{6}{|l|}{ Region } \\
\hline Zhengzhou & 126 & $3(2.4)$ & \multirow{3}{*}{$>0.05$} & $2(1.6)$ & \multirow{3}{*}{$>0.05$} \\
\hline Luoyang & 248 & $8(3.2)$ & & $6(2.4)$ & \\
\hline Nanyang & 96 & $2(2.1)$ & & $2(2.1)$ & \\
\hline \multicolumn{6}{|l|}{ Breed } \\
\hline Chinese rabbit & 324 & $9(2.8)$ & \multirow{2}{*}{$>0.05$} & $8(2.5)$ & \multirow{2}{*}{$>0.05$} \\
\hline New Zealand rabbit & 146 & $4(2.7)$ & & $2(1.4)$ & \\
\hline \multicolumn{6}{|l|}{ Sex } \\
\hline Male & 251 & $6(2.4)$ & \multirow{3}{*}{$>0.05$} & $4(1.6)$ & \multirow{3}{*}{$>0.05$} \\
\hline Female & 219 & $7(3.2)$ & & $6(2.7)$ & \\
\hline Total & 470 & $13(2.8)$ & & $10(2.1)$ & \\
\hline
\end{tabular}

Table 2. Multilocus genotyping of Toxoplasma gondii from domestic rabbits in Henan Province, central China.

\begin{tabular}{|c|c|c|c|c|c|c|c|c|c|c|c|c|c|c|}
\hline Isolate ID & Host & Location & SAG1 & $\begin{array}{l}5^{\prime}+3^{\prime} \\
\text { SAG2 } \\
\end{array}$ & $\begin{array}{c}\text { alt. } \\
\text { SAG2 }\end{array}$ & SAG3 & BTUB & GRA6 & $\mathrm{C} 22-8$ & C29-2 & L358 & PK1 & Apico & Genotype \\
\hline GT1, reference & Goat & USA & I & I & I & I & I & I & I & I & I & I & I & Type I, ToxoDB \#10 \\
\hline PTG, reference & Sheep & USA & II/III & II & II & II & II & II & II & II & II & II & II & Type II, ToxoDB \#1 \\
\hline $\begin{array}{l}\mathrm{CTG}, \\
\text { reference }\end{array}$ & Cat & USA & II/III & III & III & III & III & III & III & III & III & III & III & Type III, ToxoDB \#2 \\
\hline $\begin{array}{l}\text { MAS, } \\
\text { reference }\end{array}$ & Human & France & $\mathrm{u}-1^{\mathrm{a}}$ & I & II & III & III & III & $\mathrm{u}-1$ & I & I & III & I & ToxoDB \#17 \\
\hline TgPHN1 & Pig & Henan & $\mathrm{u}-1$ & II & II & III & III & II & II & III & II & II & I & \#9 [19] \\
\hline TgRbHN1 & Rabbit & Luoyang & $\mathrm{u}-1$ & II & II & III & III & II & II & III & II & II & $\mathrm{I}$ & ToxoDB \#9 \\
\hline TgRbHN2 & Rabbit & Luoyang & $\mathrm{u}-1$ & II & nd & III & nd & II & nd & nd & nd & nd & nd & \\
\hline TgRbHN3 & Rabbit & Nanyang & $\mathrm{u}-1$ & nd & nd & III & nd & nd & nd & nd & nd & nd & nd & \\
\hline
\end{tabular}

${ }^{\mathrm{a}} \mathrm{u}-1$ represents unique RFLP genotypes.

data suggest that ToxoDB genotype \#9 may be a prevalent lineage in rabbits in China. Further studies on a larger number of samples collected from different regions are needed to understand the genetic diversity of $T$. gondii from rabbits in China.

ITS1 sequences from the $8 \mathrm{~N}$. caninum-positive rabbits in this study showed $95-100 \%$ similarity with $N$. caninum sequences available in GenBank. Three different ITS1 sequences were identified, namely NcRb1 (from five animals, accession number MK510934), NcRb2 (from two animals, accession number MK510935), and NcRb3 (from one animal, accession number MK510936). Among these ITS1 sequences obtained in this study, NcRb1, identified from 5 out of $8 \mathrm{~N}$. caninum ITS1-positive animals and in two out of three cities, was apparently predominant. NcRb1 was identical to the majority of reference sequences available in GenBank. In the phylogenetic tree of the $N$. caninum ITS1 region, NcRb1 clusters with several representative sequences from domestic and wild animals (e.g., cattle, dogs, deer, and bats) worldwide, including two Chinese strains (JN634857 from cattle and MF802344 from bats) (Fig. 1). Minor sequence differences were observed in the ITS1 sequences NcRb2 and NcRb3, which contain a 1-bp deletion and a 1-bp mutation, respectively (Fig. 2). NcRb2 was located on an intermediate position between the two clusters where two bat-derived sequences from China also consisting of a 1-bp deletion (located as shown in Fig. 1).

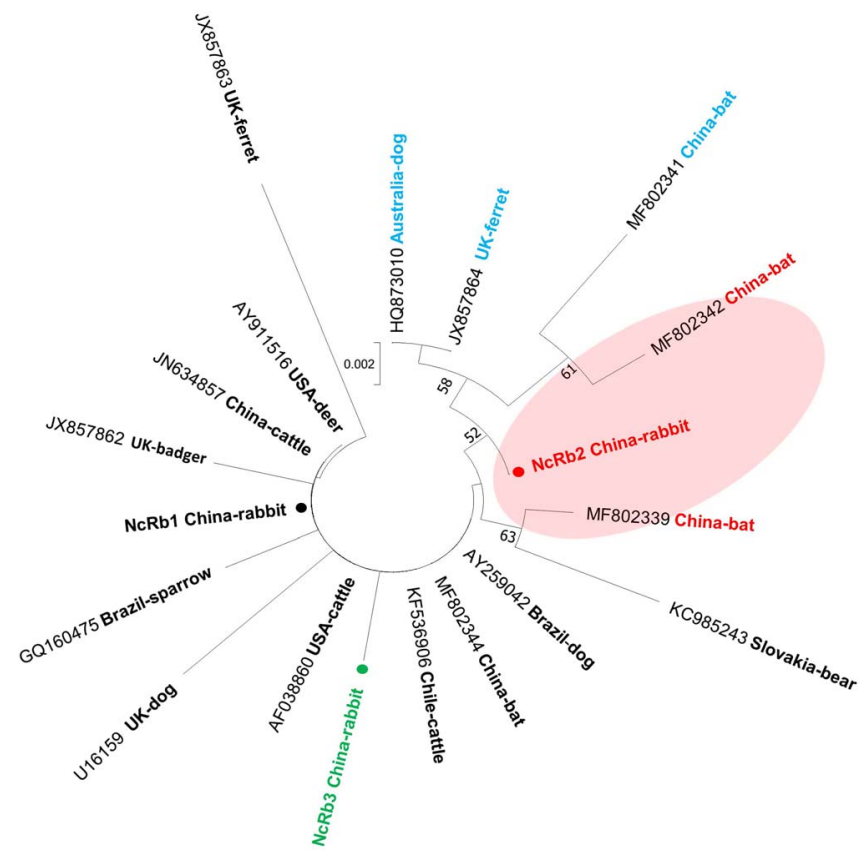

Figure 1. Phylogenetic relationships among NcRb1 - NcRb3 in this study and different representative sequences in GenBank, as inferred by a neighbor-joining analysis of the partial ITS1 region. Bootstrap values greater than $50 \%$ from 1000 pseudoreplicates are shown. The sequences in this study are marked by closed circles. 


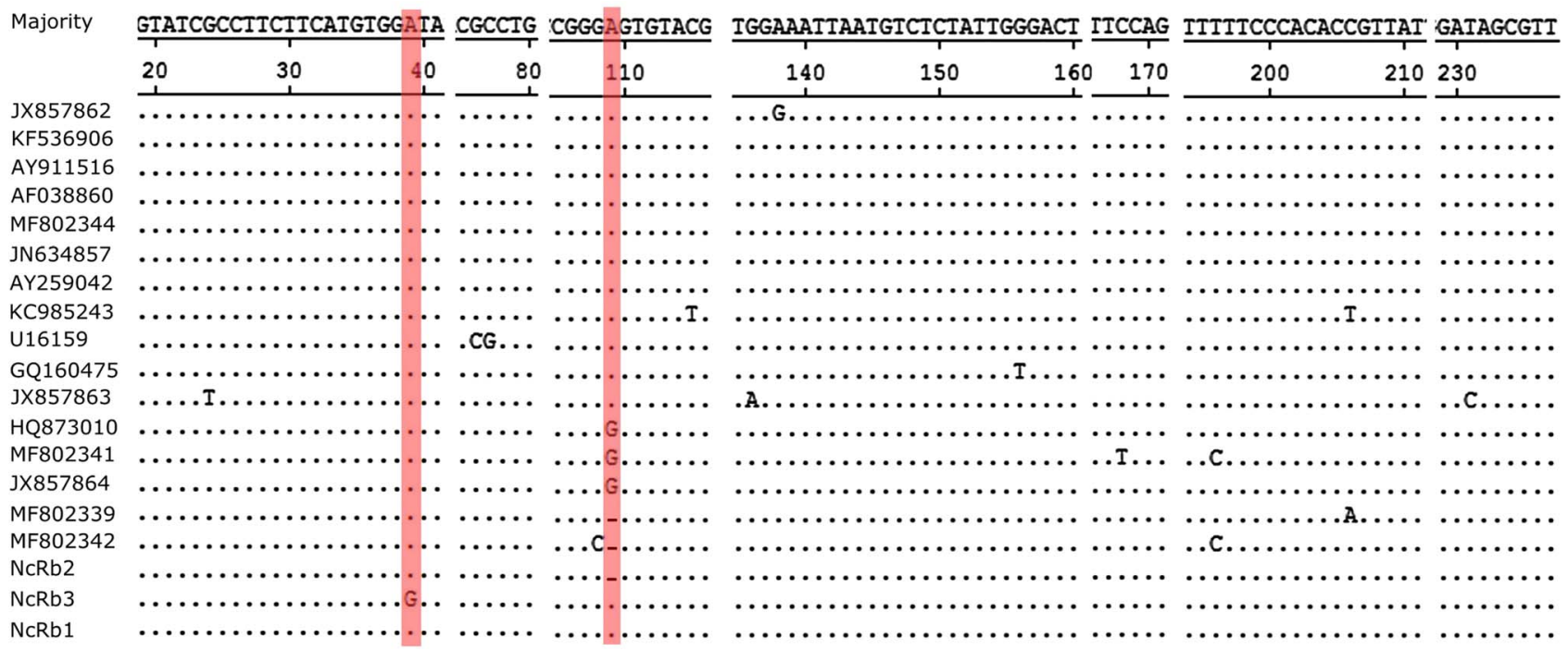

Figure 2. Sequence alignment of the partial ITS1 gene for the Neospora caninum isolates obtained in this study and reference sequences from GenBank. Dots (.) indicate identical nucleotides related to the sequence of JX857862 (first row) at that position and dashes (-) indicate deletions.

Due to low DNA concentrations, the $N$. caninum NC5 gene positive DNA samples from six rabbits gave genotyping results only at the MS5 microsatellite locus. Two MS5 genotypes were identified, including the genotype $(\mathrm{TA})_{12}$ (accession number MK510937) from four animals, and genotype (TA) 14 (accession number MK510938) from two animals. After analyses on the complete dataset, the predominate genotype (TA) 12 has been reported previously from dogs in Luoyang, China [18], as well as from dogs and cattle in the United States, Germany, and Spain [20]. The MS5 (TA) 14 genotype was found in China for the first time, and had previously been reported from dogs and cattle in South Korea, Iran, Spain, Portugal, Mexico, Argentina, and Brazil [2, 3, 14, 20, 21]. In addition, MS5 genotypes (TA $)_{8}$ and $(\mathrm{TA})_{9}$ have been reported from cattle in the same region [19]. The above-mentioned analysis on ITS1 and MS5 sequences reveals genetic diversity of $N$. caninum in Henan Province, central China.

\section{Conclusions}

In conclusion, this is the first molecular evidence of $N$. caninum DNA in rabbits in China. Genetic characterization of rabbit-derived $N$. caninum was determined based on the ITS1 region and MS5 locus, and the results reveal genetic diversity. One $T$. gondii isolate detected was identified as ToxoDB genotype \#9 which is the major lineage in China. These findings provide new genetic information on both parasites especially $N$. caninum in rabbits, and have important implications for a better understanding of the genetic diversity of the parasites in China.

\section{Competing interests}

The authors declare that they have no competing interests.
Acknowledgements. This study was supported by the National Natural Science Foundation of China (Grant No. 31502053) and High-level Talents Fund from Henan University of Science and Technology (Grant No. 09001675).

\section{References}

1. Alvarado-Esquivel C, Torres-Berumen JL, Estrada-Martinez S, Liesenfeld O, Mercado-Suarez MF. 2011. Toxoplasma gondii infection and liver disease: a case-control study in a northern Mexican population. Parasites \& Vectors, 4, 75.

2. Basso W, Schares S, Barwald A, Herrmann DC, Conraths FJ, Pantchev N, Vrhovec MG, Schares G. 2009. Molecular comparison of Neospora caninum oocyst isolates from naturally infected dogs with cell culture-derived tachyzoites of the same isolates using nested polymerase chain reaction to amplify microsatellite markers. Veterinary Parasitology, 160(1-2), 43-50.

3. Brom PR, Regidor-Cerrillo J, Collantes-Fernandez E, OrtegaMora LM, Guimaraes MS, da Silva AC. 2014. Genetic characterisation of Neospora caninum strains from clinical samples of zebuine foetuses obtained in abattoirs in Goias, Brazil. Veterinary Parasitology, 204(3-4), 381-387.

4. Cong W, Zhou CX, Chen L, Zou Y, Wang WL, Meng QF, Qian AD. 2018. Toxoplasma gondii and Neospora caninum in Tolai Hares (Lepus tolai) intended for human consumption in China: seroprevalence, DNA detection, and genotyping. Foodborne Pathogens and Disease, 15(9), 544-547.

5. de Lima DC, Santos Ade S, da Silva LT, de Melo RP, da Silva JG, Junior JW, Mota RA. 2016. Occurrence of Toxoplasma gondii in domestic rabbits of Northeastern Brazil. Acta Parasitologica, 61(3), 500-507.

6. do Nascimento LC, Pena HFJ, Leite Filho RV, Argenta FF, Alves BF, Oliveira S, Gennari SM, Driemeier D. 2017. Rare case of acute toxoplasmosis in a domestic rabbit (Oryctolagus cuniculus) in Brazil associated with the type Br III Brazilian clonal lineage of Toxoplasma gondii. Parasitology Research, 116(10), 2873-2876. 
7. Dubey JP, Carpenter JL, Speer CA, Topper MJ, Uggla A. 1988. Newly recognized fatal protozoan disease of dogs. Journal of the American Veterinary Medical Association, 192(9), 1269-1285.

8. Dubey JP. 2010. Toxoplasmosis of animals and humans, 2nd edn. CRC Press, Taylor \& Francis Group: Boca Raton, Florida. pp. 1-117, 313.

9. Dubey JP, Hemphill A, Calero-Bernal R, Schares G. 2017. Neosporosis of animals. CRC Press: Boca Raton, Florida.

10. Ellis JT, Amoyal G, Ryce C, Harper PA, Clough KA, Homan WL, Brindley PJ. 1998. Comparison of the large subunit ribosomal DNA of Neospora and Toxoplasma and development of a new genetic marker for their differentiation based on the D2 domain. Molecular and Cellular Probes, 12(1), 1-13.

11. Gondim LS, Abe-Sandes K, Uzeda RS, Silva MS, Santos SL, Mota RA, Vilela SM, Gondim LF. 2010. Toxoplasma gondii and Neospora caninum in sparrows (Passer domesticus) in the Northeast of Brazil. Veterinary Parasitology, 168(1-2), 121-124.

12. Hughes JM, Thomasson D, Craig PS, Georgin S, Pickles A, Hide G. 2008. Neospora caninum: detection in wild rabbits and investigation of co-infection with Toxoplasma gondii by PCR analysis. Experimental Parasitology, 120(3), 255-260.

13. Luo H, Li K, Shahzad M, Zhang H, Lan Y, Xiong X. 2017. Seroprevalence of Toxoplasma gondii infection in wild boars, wild rabbits, and wild chickens in Hubei Province, China. Korean Journal of Parasitology, 55(1), 85-88.

14. Medina-Esparza L, Regidor-Cerrillo J, Garcia-Ramos D, Alvarez-Garcia G, Benavides J, Ortega-Mora LM, CruzVazquez C. 2016. Genetic characterization of Neospora caninum from aborted bovine foetuses in Aguascalientes, Mexico. Veterinary Parasitology, 228, 183-187.

15. Meng QF, Wang WL, Ni XT, Li HB, Yao GZ, Sun XL, Wang WL, Cong W. 2015. Seroprevalence of Encephalitozoon cuniculi and Toxoplasma gondii in domestic rabbits (Oryctolagus cuniculus) in China. Korean Journal of Parasitology, 53(6), 759-763.

16. Qian WF, Yan WC, Wang TQ, Shao XD, Zhai K, Han LF, Lv CC. 2015. Genetic characterization of Toxoplasma gondii from domestic animals in Central China. Tropical Biomedicine, 32(3), 540-544.

17. Qian WF, Yan WC, Wang TQ, Zhai K, Han LF, Lv CC. 2015. Prevalence and genetic characterization of Toxoplasma gondii in pet dogs in Central China. Korean Journal of Parasitology, 53(1), 125-128.
18. Qian W, Wang T, Yan W, Han L, Zhai K, Duan B, Lv C. 2016. Occurrence and first multilocus microsatellite genotyping of Neospora caninum from naturally infected dogs in dairy farms in Henan, Central China. Parasitology Research, 115(8), 3267-3273.

19. Qian W, Wang T, Yan W, Zhang M, Han L, Xue R, Song S, Lv C. 2017. Seroprevalence and first multilocus microsatellite genotyping of Neospora caninum in dairy cattle in Henan, Central China. Veterinary Parasitology, 244, 81-84.

20. Regidor-Cerrillo J, Diez-Fuertes F, Garcia-Culebras A, Moore DP, Gonzalez-Warleta M, Cuevas C, Schares G, Katzer F, Pedraza-Diaz S, Mezo M, Ortega-Mora LM. 2013. Genetic diversity and geographic population structure of bovine Neospora caninum determined by microsatellite genotyping analysis. PLoS One, 8(8), e72678.

21. Salehi N, Gottstein B, Haddadzadeh HR. 2015. Genetic diversity of bovine Neospora caninum determined by microsatellite markers. Parasitology International, 64(5), 357-361.

22. Su C, Shwab EK, Zhou P, Zhu XQ, Dubey JP. 2010. Moving towards an integrated approach to molecular detection and identification of Toxoplasma gondii. Parasitology, 137(1), 1-11.

23. Wang H, Zhang L, Ren Q, Yu F, Yang Y. 2017. Diagnosis of Swine Toxoplasmosis by PCR and Genotyping of Toxoplasma gondii from pigs in Henan, Central China. BMC Veterinary Research, 13(1), 152.

24. Wang S, Yao Z, Li L, Pan Y, Li P, Nan X, Xie Q, Zhang Z. 2018. Seroprevalence of Toxoplasma gondii and Encephalitozoon cuniculi among domestic rabbits in Central China. Parasite, 25, 9.

25. Wang T, Han Y, Pan Z, Wang H, Yuan M, Lin H. 2018. Seroprevalence of Toxoplasma gondii infection in blood donors in mainland China: a systematic review and meta-analysis. Parasite, 25, 36.

26. Zanet S, Palese V, Trisciuoglio A, Canton Alonso C, Ferroglio E. 2013. Encephalitozoon cuniculi, Toxoplasma gondii and Neospora caninum infection in invasive eastern cottontail rabbits Sylvilagus floridanus in Northwestern Italy. Veterinary Parasitology, 197(3-4), 682-684.

27. Zhou Y, Zhang H, Cao J, Gong H, Zhou J. 2013. Isolation and genotyping of Toxoplasma gondii from domestic rabbits in China to reveal the prevalence of type III strains. Veterinary Parasitology, 193(1-3), 270-276.

Cite this article as: Qian W, Yan W, Lv C, Bai R \& Wang T. 2019. Occurrence and genetic characterization of Toxoplasma gondii and Neospora caninum in slaughtered domestic rabbits in central China. Parasite 26, 36.

Reviews, articles and short notes may be submitted. Fields include, but are not limited to: general, medical and veterinary parasitology; morphology, including ultrastructure; parasite systematics, including entomology, acarology, helminthology and protistology, and molecular analyses; molecular biology and biochemistry; immunology of parasitic diseases; host-parasite relationships; ecology and life history of parasites; epidemiology; therapeutics; new diagnostic tools.

All papers in Parasite are published in English. Manuscripts should have a broad interest and must not have been published or submitted elsewhere. No limit is imposed on the length of manuscripts.

Parasite (open-access) continues Parasite (print and online editions, 1994-2012) and Annales de Parasitologie Humaine et Comparée (1923-1993) and is the official journal of the Société Française de Parasitologie. 